\title{
HELICOBACTER PYLORI INFECTION IN PATIENTS WITH DIFFERENT GASTROINTESTINAL DISEASES FROM NORTHERN BRAZIL
}

\author{
Igor Dias Ferreira VINAGRE ${ }^{1}$, André Lima de QUEIROZ1', \\ Mário Ribeiro da SILVA JÚNIOR ${ }^{2}$, Ruth Maria Dias Ferreira VINAGRE ${ }^{3}$ \\ and Luisa Caricio MARTINS ${ }^{4}$
}

\begin{abstract}
Background - The mechanisms whereby Helicobacter pylori produces different pathological manifestations in the stomach and duodenum are not fully understood. Considering the geographic diversity in the prevalence of virulence factors of this microorganism and their association with the development of different diseases, the search for pathogenicity markers such as CagA and VacA alleles by molecular techniques has intensified. Objectives - To investigate the presence of H. pylori infection and the frequency of different genotypes of this bacterium in patients with gastrointestinal diseases from Northern Brazil, and to establish their association with the histopathological findings. Methods - In a prospective study, samples were collected from 554 patients with different gastrointestinal diseases (gastritis, duodenal ulcer, gastric ulcer, and gastric cancer) seen at a referral hospital attending the entire State of Pará, located in the metropolitan region of Belém. Data such as gender and age obtained with an epidemiological questionnaire were analyzed. The presence of $H$. pylori and the bacterial genotype were investigated by PCR. Gastric biopsies were assessed histologically. Results - The prevalence of $\mathrm{H}$. pylori infection was $91 \%$. Infection was more frequent among patients with gastric ulcer and gastric cancer. In these groups, there was a predominance of men and older patients when compared to the other two groups studied. The predominant bacterial genotype was $\mathrm{s} 1 \mathrm{~m} 1 \mathrm{cagA}+$, which was more frequent among patients with gastric ulcer, duodenal ulcer and gastric cancer. A significant association was observed between s1m1cagA + strains and a higher degree of inflammation, neutrophil activity and development of intestinal metaplasia. Conclusion - The present study demonstrates a high incidence of $H$. pylori infection in the patients analyzed, especially among those with gastric ulcer and gastric cancer. Virulent slm$1 \mathrm{cag} A+$ strains predominated and were associated with more severe lesions.
\end{abstract}

HEADINGS - Helicobacter pylori. Helicobacter infections. Gastrointestinal diseases. Genotype.

\section{INTRODUCTION}

Infection with Helicobacter pylori induces persistent inflammation in the gastric mucosa, causing gastritis in almost all infected individuals. Although most hosts remain asymptomatic, others develop peptic or duodenal ulcers, gastric adenocarcinoma and lymphomas, especially mucosa-associated lymphoid tissue (MALT) lymphoma ${ }^{(26)}$. The mechanism whereby the bacterium produces different pathological manifestations in the stomach and duodenum are not fully understood. In this respect, bacterial virulence factors, environmental factors and host genetic factors probably contribute to the differences in clinical evolution ${ }^{(5)}$.

Virulence factors play an important role in the pathogenesis of $H$. pylori infection, since virulent strains are more aggressive and increase the risk of developing severe clinical manifestations ${ }^{(6)}$. The most important $H$. pylori virulence factor is the cytotoxinassociated gene pathogenicity island (cag PAI). Cytotoxin-associated gene A (CagA) is a protein with a molecular mass of approximately 125-140 $\mathrm{kDa}$, which is encoded by the cagA gene. The protein is translocated into gastric epithelial cells by a type IV secretion system, encoded by the cag pathogenicity island (cag PAI) ${ }^{(23)}$. Inside epithelial cells, CagA is phosphorylated on tyrosine residues by host cell Src kinases and stimulates cell signaling pathways ${ }^{(29)}$ which, in turn, cause elongation of the cell ${ }^{(30)}$ and activation of proto-oncogenes ${ }^{(19)}$.

VacA, or vacuolating cytotoxin, is another virulence factor that plays a key role in the pathogenesis of $H$. pylori. Three cellular activities of this protein have been confirmed: cell vacuolation, apoptosis, and CD4+ T-lymphocyte activation and proliferation ${ }^{(27)}$.

${ }^{1}$ Universidade Federal do Pará, Belém, PA, Brasil; ${ }^{2}$ Departamento de Gastroenterologia, Hospital Santo Antonio Maria Zaccaria, Bragança, PA, Brasil; ${ }^{3}$ Departamento de Clínica Médica, Hospital Ofir Loiola, Belém, PA, Brasil; ${ }^{4}$ Laboratório de Patologia Clínica de Doenças Tropicais, Universidade Federal do Pará, Belém, PA, Brasil. Correspondence: Luisa Caricio Martins. Trav. Mauriti, 3269, ap. 704 B - Marco - CEP: 66095-360 - Belém, PA, Brasil. E-mail: caricio@ufpa.br 
Specific variants of the vacA allele exhibit different levels of toxin activity and are associated with different risks of gastrointestinal diseases. There are two types of signal regions (s1 and $\mathrm{s} 2$ ) and mid-regions ( $\mathrm{m} 1$ and $\mathrm{m} 2$ ) that possess different vacuolating activities. In general, genotypes vacA s1 and $\mathrm{m} 1$ produce large amounts of toxin and induce greater vacuolating activity in the gastric epithelium, while genotypes $\mathrm{s} 2$ and $\mathrm{m} 2$ produce little or no toxin. VacA s2-m2 strains are rarely associated with the development of peptic ulcer and gastric cancer ${ }^{(32)}$.

Helicobacter pylori strains have been divided into two groups: type I (cag+/s1m1 VacA) that causes ulceration and cancer, and type II (cag-/s2m2 VacA) that induces less inflammation and tissue damage ${ }^{(26)}$.

Since considerable geographic diversity in the prevalence of $H$. pylori virulence factors has been reported, the objective of the present study was to investigate the presence of $H$. pylori infection and the frequency of association of different bacterial genotypes with gastrointestinal diseases in 554 patients seen at a referral hospital in the Metropolitan Region of Belém, Pará, Brazil, as well as their association with different histopathological findings. The hospital receives patients from across the State of Pará.

\section{METHODS}

\section{Patients}

Gastric biopsies were collected from 554 patients with different gastrointestinal disorders seen at the endoscopy sector of the Ofir Loiola Hospital from 2013 to 2014. This Hospital is a reference in cancer treatment and receives patients from throughout the region suspected of having this disease for diagnostic investigation.

A specific questionnaire elaborated and applied by the authors and completed by the patients was used to obtain data such as gender, age, and symptoms. The patients agreed to participate in the study by signing a free informed consent form.

During endoscopy, four biopsy fragments were obtained from the stomach of each patient. Biopsies of the lesion and perilesional mucosal area were obtained from each patient for histological analysis and two antrum specimens were also analyzed using molecular methods. None of the patients had received antimicrobial drugs, $\mathrm{H} 2$-receptor antagonists, acid pump inhibitors, nonsteroidal anti-inflammatory drugs, or any medication for at least 60 days prior to endoscopy.

All patients included were of low socioeconomic level and had similar cultural habits. All patients were born in Pará State and had the same ethnic background, approximately $50 \%$ Portuguese, $40 \%$ Amerindian and $10 \%$ African $^{(28)}$. The study was approved by the Ethics Committee of the Center of Tropical Medicine, Federal University of Pará.

\section{Extraction of DNA and PCR}

Gastric fragments were collected from the antrum of each patient for histopathological analysis and extraction of bacterial DNA ${ }^{(17)}$. Total DNA was extracted from frozen gastric biopsy specimens using the following procedure: 10 $\mathrm{mL}$ proteinase $\mathrm{K}$ and $300 \mathrm{~mL}$ lysis buffer $(200 \mathrm{mM}$ Tris$\mathrm{HCl}, 25 \mathrm{mM}$ EDTA, $300 \mathrm{mM} \mathrm{NaCl}, 1.2 \%$ sodium dodecyl sulfate) were added to the biopsy specimens and the mixture was incubated at $55^{\circ} \mathrm{C}$ for $12 \mathrm{~h}$. The lysate was extracted with an equal volume of phenol-chloroform, precipitated with isopropanol, and washed with $70 \%$ ethanol. The pellet was dried and suspended in $200 \mathrm{ml}$ sterile distilled water. The extracted DNA was stored at $-20^{\circ} \mathrm{C}$.

A set of primers ( $\mathrm{p} 1$ and $\mathrm{p} 2)^{(13)}$ that amplify a gene fragment of $298 \mathrm{bp}$ found in all $\mathrm{H}$. pylori strains was used to detect bacterial DNA. Only positive samples were used for amplification of the cagA gene.

The protocol and primers described by Tummuru et al. ${ }^{(34)}$ were used for amplification of the cagA gene. Negative and positive controls were included in all reactions. The PCR products were separated by electrophoresis on $2 \%$ agarose gel stained with ethidium bromide and visualized under a UV transilluminator.

\section{Histopathological analysis}

Hematoxylin-eosin staining was used for histopathological analysis of the gastric biopsies. The histopathological parameters were scored from 0-3 according to criteria of the Sydney System for analysis of polymorphonuclear and mononuclear cell infiltration ${ }^{(20)}$.

\section{Statistical analysis}

The chi-square test and $\mathrm{G}$ test were used to compare frequencies between groups. Risk factors were estimated by univariate analysis using odds ratios. Statistical significance was accepted at a level of $95 \%$. The BioEstat 5.0 program was used for data analysis ${ }^{(4)}$.

\section{RESULTS}

A total of 554 patients with different gastrointestinal diseases were analyzed; of these, $49.3 \%(273 / 554)$ had gastritis, $9.9 \%(55 / 554)$ had gastric ulcers, $13.4 \%(74 / 554)$ had duodenal ulcers, and $27.4 \%(152 / 554)$ had gastric adenocarcinoma. Of the 273 patients with gastritis, $73 \%(200 / 273)$ were superficial type, $22 \%(61 / 273)$ erosive and 5\% (12/273) atrophic.

\section{Epidemiological and histopathological data}

Table 1 shows the comparison of the frequency of gender, age, $H$. pylori infection and histopathological data between groups. Among the patients studied, 58.1\% (322/554) were males and $41.9 \%(232 / 554)$ were females. There was a predominance of male patients among those with gastric ulcer $\left(\chi^{2}=8.81, P<0.01\right)$ and gastric cancer $\left(\chi^{2}=7.38, P<0.01\right)$ when compared to patients with gastritis and duodenal ulcer.

Patient age ranged from 18 to 91 years, with a mean age of 43.8 years in patients with gastritis, 43 years in patients with duodenal ulcer, 53.8 years in patients with gastric ulcer, and 51.5 years in the group with gastric cancer. Patients with gastric ulcer and cancer were older than those of the other two groups studied $\left(\chi^{2}=4.5,6 P<0.01\right)$. 
TABLE 1. Epidemiological and histopathological data of patients with different gastrointestinal diseases

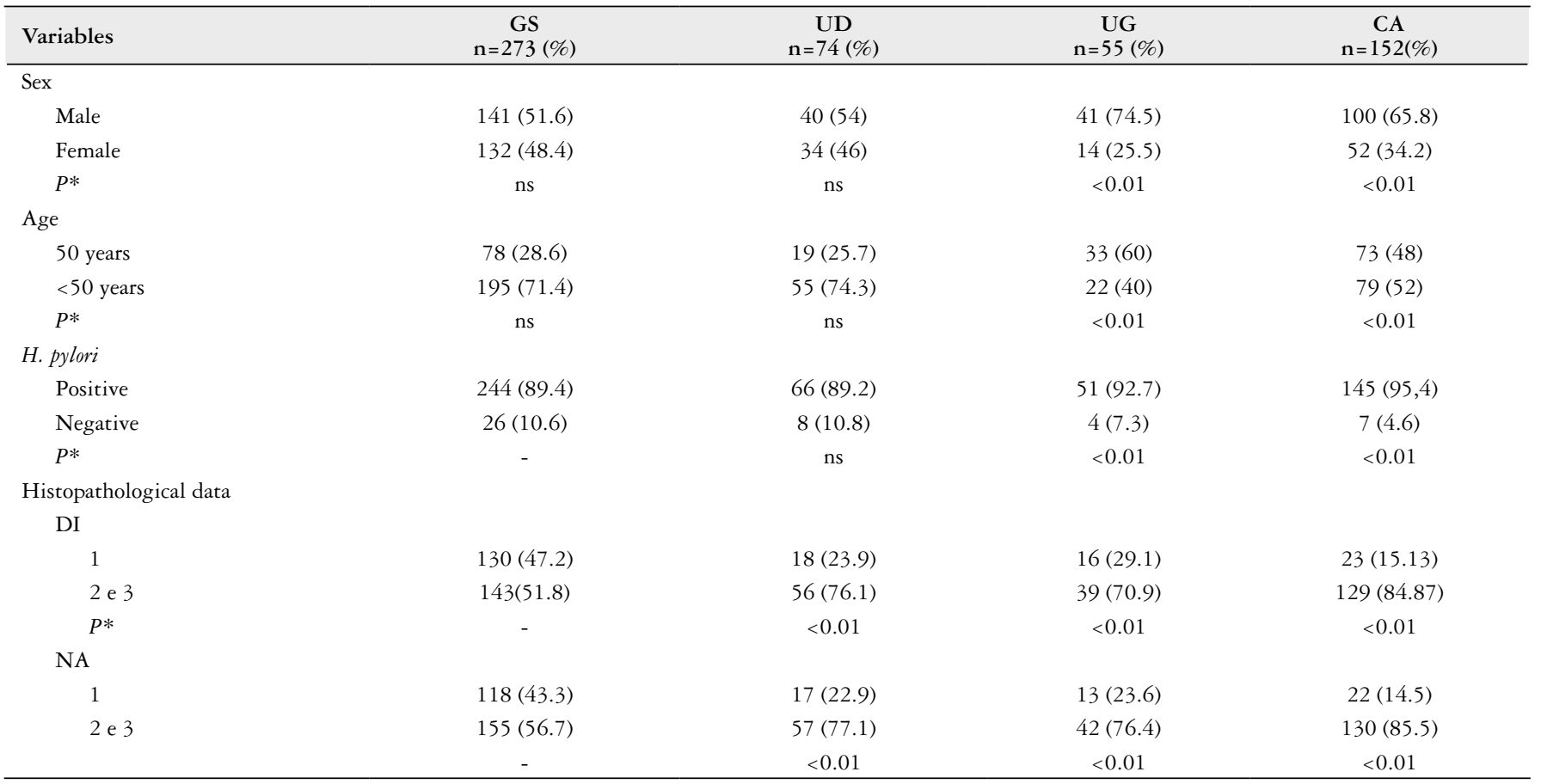

G test ns: not significant; DU: duodenal ulcer; GU: gastric ulcer; GC: gastric cancer; DI: degree of inflammation; NA: neutrophil activity. $1=$ mild, $2=$ moderate, $3=$ intense.

In the histological analysis, 34\% (187/554) of the biopsies showed mild degree of inflammation, 37\% (207/554) moderate, and 29\% (160/554) intense. Neutrophil activity in $30 \%$ of biopsies (170/554) were mild, $39 \%(214 / 554)$ were moderate and 31\% (170/554) intense. Comparing the histopathological data between different diseases studied, it was observed that patients with duodenal ulcer, gastric ulcer and gastric adenocarcinoma exhibited a higher degree of inflammation and neutrophil activity than patients with gastritis.

Investigation of $H$. pylori infection by a molecular biology method (PCR) detected bacterial DNA in gastric biopsies of $91 \%(506 / 554)$ of the cases analyzed. Helicobacter pylori was detected in $89.4 \%(244 / 273)$ of patients with gastritis, $89.2 \%$ $(66 / 74)$ of patients with duodenal ulcer, $92.7 \%(51 / 55)$ of patients with gastric ulcer, and $95.4 \%$ (145/152) of patients with gastric cancer.

\section{Genotyping of $\boldsymbol{H}$. pylori vacA and cagA genes}

Characterization of the vacA alleles of the bacterial strains showed that all isolates carried the vacA gene. Among the patients analyzed, 97.6\% (494/506) were colonized with only one strain, which exhibited only one vacA genotype (s1/ $\mathrm{m} 1$ or $\mathrm{s} 1 / \mathrm{m} 2$ or $\mathrm{s} 2 \mathrm{~m} 2)$, and $2.4 \%(12 / 506)$ were infected with more than one strain, with the detection of more than one vacA genotype (s1/m1 and $\mathrm{s} 2 / \mathrm{m} 2)$.

Analysis of the vacA gene showed that 88\% (446/506) of the patients carried allele s1 of the signal region of the gene. There was a predominance of allele $\mathrm{m} 1$ of the mid-region in $87 \%(440 / 506)$ of the patients. In patients with monoinfection, $86.6 \%(428 / 494)$ of the bacterial strains detected carried the $\mathrm{s} 1 / \mathrm{m} 1$ genotype, $1.2 \%(6 / 494)$ the $\mathrm{s} 1 / \mathrm{m} 2$ genotype, and $12.2 \%(60 / 494)$ the $\mathrm{s} 2 / \mathrm{m} 2$ genotype.

The cagA gene was detected in $85.6 \%(433 / 506)$ of the patients infected with $H$. pylori. With respect to gastrointestinal diseases, the presence of the cagA gene was observed in $80.3 \%$ (196/244) of patients with gastritis, in $98.5 \%$ (65/66) of patients with duodenal ulcer, in $88.2 \%(45 / 51)$ of patients with gastric ulcer, and in $88.3 \%(128 / 145)$ of patients with gastric cancer.

Comparison of the different vacA alleles and presence or absence of cagA showed a higher prevalence of virulent s1m1cagA+ strains in patients with monoinfection. A predominance of the $1 \mathrm{~m} 1 / \mathrm{s} 2 \mathrm{~m} 2 \mathrm{cagA}+$ genotype was observed in patients infected with multiple strains. Another genotype found in mixed infections was $\mathrm{s} 1 \mathrm{~m} 1 / \mathrm{s} 2 \mathrm{~m} 2 \mathrm{cagA}$ - (Table 2).

TABLE 2. Frequency of different bacterial genotypes detected in all patients studied

\begin{tabular}{lcc}
\hline Genotype & Frequency & $\%$ \\
\hline Monoinfection & 422 & 83.4 \\
s1m1cagA+ & 6 & 1.2 \\
s1m1cagA- & 6 & 1.2 \\
s1m2cagA- & 60 & 11.8 \\
s2m2cagA- & & \\
Mixed infection & 11 & 2.2 \\
s1m1/s2m2 cagA+ & 1 & 0.2 \\
s1m1/s2m2 cagA- & 506 & 100.0 \\
Total & & \\
\hline
\end{tabular}




\section{Frequency of different genotypes in patients with gastrointestinal diseases}

Analysis of the correlation between the endoscopic diagnosis of gastrointestinal disease and $H$. pylori strains showed that virulent s1m1cagA+ strains were more frequent in patients with gastric ulcer $(\mathrm{G}=34.18 ; P=0.01)$, duodenal ulcer $(\mathrm{G}=62.04 ; P=0.01)$, and gastric cancer $(\mathrm{G}=2.29 ; P=0.12))$ compared to patients with gastritis. The comparison of strains between the group with gastric ulcer and the groups with duodenal ulcer $(\mathrm{G}=62.04 ; P=0.01)$ and gastric cancer $(\mathrm{G}=0.016 ; P=0.89)$ was not significant. Table 3 shows the frequency of the different genotypes in patients with gastrointestinal diseases.

TABLE 3. Prevalence of cytotoxin-associated gene (cagA) and allele combinations of the vacA gene in patients with different gastrointestinal diseases

\begin{tabular}{lcccc}
\hline Genotype & $\begin{array}{c}\text { Gastritis \% } \\
\mathbf{n}=244\end{array}$ & $\begin{array}{c}\text { GU \% } \\
\mathbf{n}=51\end{array}$ & $\begin{array}{c}\text { Cancer } \% \\
\mathbf{n}=145\end{array}$ & $\begin{array}{c}\text { DU \% } \\
\mathbf{n}=66\end{array}$ \\
\hline Monoinfection & & & & \\
$\quad$ s1-m1-cagA+ & $188(77)$ & $44(86.3)$ & $126(86.9)$ & $64(97)$ \\
$\quad$ NV & $48(19.7)$ & $6(11.8)$ & $16(11)$ & $2(3)$
\end{tabular}

Mixed infection

$\begin{array}{lccc}\mathrm{s} 1 \mathrm{~m} 1 \backslash \mathrm{s} 2 \mathrm{~m} 2 \mathrm{cag} A+ & 8(3.3) & 1(1.9) & 2(1.4) \\ \mathrm{s} 1 \mathrm{~m} 1 \backslash \mathrm{s} 1 \mathrm{~m} 2 \mathrm{cagA}- & - & - & 1(0.7)\end{array}$

GU: gastric ulcer; DU: duodenal ulcer; NV: non-virulent strain (s1-m1-cagA-, s1-m2-cagA-, s2-m2-cagA-).

\section{Association between $\boldsymbol{H}$. pylori genotypes and histo- pathological findings}

Only patients with monoinfection $(n=494)$ were studied since the number of patients with mixed infection was not statistically significant for this analysis. Patients infected with s1m1cagA+ strains exhibited a higher degree of inflammation and neutrophil activity than patients infected with other strains (Table 4).

TABLE 4. Association of the different vacA alleles and presence of the cagA gene with histopathological data (degree of inflammation and neutrophil activity) in monoinfected patients

\begin{tabular}{|c|c|c|c|c|c|c|c|}
\hline \multirow{2}{*}{$\begin{array}{l}\text { vacA } \\
\text { Alleles }\end{array}$} & \multirow[t]{2}{*}{$\operatorname{cag} A$} & \multicolumn{2}{|r|}{ DI } & \multirow{2}{*}{$\begin{array}{c}\text { OR/P-value } \\
(95 \% \mathrm{CI})\end{array}$} & \multicolumn{2}{|c|}{ NA } & \multirow{2}{*}{$\begin{array}{c}\text { OR/P-value } \\
(95 \% \mathrm{CI})\end{array}$} \\
\hline & & 1 & 2 and 3 & & 1 & 2 and 3 & \\
\hline $\mathrm{s} 1 \mathrm{~m} 1$ & $(+)$ & 96 & 326 & - & 86 & 336 & \\
\hline $\mathrm{s} 1 \mathrm{~m} 1$ & $(-)$ & 1 & 5 & $8.24 / 0.01$ & 3 & 3 & $11.72 / 0.01$ \\
\hline $\mathrm{s} 1 \mathrm{~m} 2$ & $(-)$ & 6 & - & $(4.72-14.39)$ & 6 & - & $(6.53-21.01)$ \\
\hline $\mathrm{s} 1 \mathrm{~m} 2$ & $(-)$ & 44 & 16 & & 45 & 15 & \\
\hline
\end{tabular}

OR: odds ratio; $95 \% \mathrm{CI}$ : 95\% confidence interval; DI: degree of inflammation; NA: neutrophil activity. $1=$ mild, $2=$ moderate, 3 =intense.
Metaplasia was observed in $24.5 \%$ (121/494) of patients with monoinfection. The bacterial genotype s1m1cagA+ was identified in the gastric mucosa of most of these patients (Table 5).

TABLE 5. Association of the different vacA alleles and presence of the cag A gene with intestinal metaplasia

\begin{tabular}{|c|c|c|c|c|}
\hline \multirow{2}{*}{$\begin{array}{l}\text { vacA } \\
\text { Alleles }\end{array}$} & \multirow[t]{2}{*}{$\operatorname{cag} A$} & \multicolumn{2}{|c|}{ Metaplasia } & \multirow{2}{*}{$\begin{array}{c}\text { OR/P-value } \\
(95 \% \mathrm{CI})\end{array}$} \\
\hline & & Present & Absent & \\
\hline $\mathrm{s} 1 \mathrm{~m} 1$ & $(+)$ & 117 & 305 & \\
\hline $\mathrm{s} 1 \mathrm{~m} 1$ & $(-)$ & 1 & 5 & $7.28 / 0.03$ \\
\hline $\mathrm{s} 1 \mathrm{~m} 2$ & $(-)$ & - & 6 & $(2.23-23.72)$ \\
\hline $\mathrm{s} 1 \mathrm{~m} 2$ & $(-)$ & 3 & 57 & \\
\hline
\end{tabular}

OR: odds ratio; $95 \% \mathrm{CI}=95 \%$ confidence interval.

\section{DISCUSSION}

Several authors have demonstrated differences in the geographical distribution of $H$. pylori genotypes, which directly influence the clinical relevance of the strains ${ }^{(35)}$. This study was conducted to increase knowledge regarding the prevalence of $H$. pylori virulence factors in the State of Pará, Northern Brazil. Additionally, infection with this bacterium was related to different gastrointestinal diseases and to the histopathological alterations found in these cases.

The largest number of cases of gastric cancer was due to the study had been conducted at a cancer referral hospital endoscopy service in the region.

A predominance of males was observed among patients with gastric ulcer and gastric cancer. These patients were older than those of the other two groups studied. This higher frequency of gastric ulcers and cancer among men has been associated with lifestyle, since men are more frequently exposed to stress and environmental factors related to habits such as alcohol consumption and smoking ${ }^{(9)}$. The higher incidence of gastric ulcers and cancer in individuals older than 50 years has been related to sequential changes characterized by metaplastic alterations that occur in the gastric mucosa secondary to infection with $H$. pylori $i^{(9,16)}$.

Detection of infection with $H$. pylori by a molecular biology method (PCR) revealed a prevalence of $91 \%$ among patients with different gastrointestinal diseases. A high incidence of gastric carcinoma and peptic ulcer, as well as a high prevalence of infection with $H$. pylori, is observed in Brazil, especially in the State of Pará ${ }^{(1,18,36,37)}$.

Some characteristics of $H$. pylori strains have been associated with the progression of infection to more severe disease. In this respect, some genotypes, such as alleles $\mathrm{s} 1$ and $\mathrm{m} 1$ of the vacA gene and presence of the cagA gene, are considered pathogenicity markers since they are associated with cytotoxin production and the induction of more intense epithelial lesions and inflammatory reactions. In many countries, these genotypes have been associated with the progression of infection to diseases such as peptic ulcer and gastric adenocarcinoma ${ }^{(1,3,10,12,14,22,31,38)}$. 
The cagA gene was identified in $85.6 \%$ of the patients with gastrointestinal diseases studied. Similar results have been reported in other studies conducted in the State of Pará ${ }^{(31,38)}$ and in other Brazilian states, as well as in other countries $^{(2,11,25,40)}$. When only $H$. pylori-positive patients were compared between the four groups studied, an even stronger association was observed between infection with cagA-positive H. pylori strains and gastrointestinal diseases. Analysis of the different diseases showed a higher frequency of the cagA gene in $H$. pylori-positive patients with duodenal ulcer compared to patients with gastritis, gastric ulcer and gastric cancer. Queiroz et al. ${ }^{(24)}$ found that, in Brazil, $95.0 \%$ and $62.3 \%$ of strains isolated from children with and without duodenal ulcers are $\operatorname{cag} A$-positive, respectively. Other studies have reported a higher frequency of the cagA gene in $H$. pyloripositive patients with peptic ulcer and gastric cancer ${ }^{(17,33,38)}$.

In the present study, $97.6 \%$ of the patients were infected with only one type of bacterial strain (monoinfection) and $2.4 \%$ were infected with more than one type of strain (mixed infection). In Brazil, the frequency of multiple infections ranges from $3.4 \%$ to $17 \%$ depending on the populations involved and the region where the study was conducted ${ }^{(2,17,33,37)}$.

Characterization of the vacA alleles and investigation of the presence of the cagA gene demonstrated that the predominant genotype in this study was $\mathrm{s} 1 \mathrm{~m} 1 \mathrm{cag} A+(83.4 \%)$. Previous studies conducted in the State of Pará reported a higher prevalence of this genotype in patients with different gastrointestinal diseases ${ }^{(17,31,37,38)}$. The same was observed in studies conducted in other Brazilian states such as Belo Horizonte (Minas Gerais) ${ }^{(2)}$, Salvador (Bahia) $)^{(8)}$, and Botucatu (São Paulo) $)^{(33)}$.

Analysis of the genotypes of $H$. pylori contributes to explain the distribution of gastrointestinal diseases around the world, given the fact that, although the prevalence of $H$. pylori infection is higher in developing countries, some developed countries such as Japan, Portugal and Spain have high frequencies of severe gastrointestinal diseases such as peptic ulcers and gastric cancer. Studies conducted in these countries have associated this fact with the local predominance of $H$. pylori strains carrying genotype $\mathrm{s} / \mathrm{b} /$ $\mathrm{m} 1 / \operatorname{cag} \mathrm{A}+(15,21,35)$.
In the present study, virulent $\mathrm{s} 1 \mathrm{~m} 1 \mathrm{cag} \mathrm{A}+$ strains were more frequent in patients with gastric ulcer, duodenal ulcer and gastric cancer compared to patients with gastritis. These data indicate a greater association between infection with bacterial strains carrying this genotype $(\mathrm{s} 1 \mathrm{~m} 1 \mathrm{cag} \mathrm{A}+)$ and an increased risk of developing more severe forms of infection. This association is supported by studies conducted in Brazil and in other countries ${ }^{(7,8,17,33,37,39)}$.

With respect to the association of different alleles of the vacA gene and presence of the cagA gene with histopathological findings, we observed that patients infected with slm1cagA+ strains exhibited a high degree of inflammation and neutrophil activity in the gastric mucosa, as well as an increased risk of developing intestinal metaplasia. These findings agree with the results reported in studies conducted in Brazil and in other countries ${ }^{(2,31,37,40)}$ and support the correlation of pathogenic vacA and cagA genotypes of $H$. pylori with chronic aggression to the mucosa, which is expressed at the morphological level by an inflammatory infiltrate rich in enzymes and free radicals that damage epithelial cells ${ }^{(33)}$.

In conclusion, the results of the present study demonstrate the importance of bacterial factors, such as genotype of the infecting strain, for the pathogenesis of gastrointestinal diseases. These findings are supported by data indicating that patients infected with s $1 \mathrm{~m} 1 \mathrm{cagA}+$ strains have an increased risk of developing more severe forms of infection. These findings are useful to identify patients who are at a higher risk of developing more severe gastrointestinal diseases, and therefore contribute to the prognosis and treatment of these cases. Further studies establishing the relationship between bacterial, host and environmental factors are necessary to determine what makes a patient to develop duodenal ulcer, gastric ulcer or gastric cancer, since the distribution of the genotypes of infecting strains does not differ between patients with these diseases.

\section{Authors'contributions}

Vinagre IDF, Queiroz AL and Vinagre RMDF: responsible researcher. Silva Jr MR: examination of upper gastrointestinal endoscopy and biopsy. Martins LC: histopathological analysis and genotyping of $H$. pylori.

Vinagre IDF, Queiroz AL, Silva Jr MR, Vinagre RMDF, Martins LC. Infecção pelo Helicobacter pylori em pacientes com diferentes doenças gastrointestinais do Norte do Brasil. Arq Gastroenterol. 2015,52(4):xxx.

RESUMO - Contexto - Os mecanismos pelos quais o H. pylori produz diferentes quadros patológicos no estômago e no duodeno não são totalmente conhecidos. Considerando a diversidade geográfica relacionada à prevalência dos fatores de virulência desse microrganismo e sua associação com o desenvolvimento de diferentes doenças, vem se intensificando a pesquisa de marcadores de patogenicidade, como o CagA e os alelos do VacA por técnicas moleculares. Objetivos - O objetivo desse estudo foi investigar a presença da infecção por $H$. pylori, e a frequência dos diferentes genótipos dessa bactéria em pacientes com doenças gastrointestinais da nossa região, procurando estabelecer sua associação com os achados histopatológicos. Métodos - Em estudo prospectivo, foram coletadas amostras de 554 pacientes com diferentes doenças gastrointestinais (gastrite, úlcera duodenal, úlcera gástrica e câncer gástrico), atendidos em hospital de referência para todo o Estado do Pará, localizado na região metropolitana de Belém. Foram analisados dados obtidos através de questionário epidemiológico, relacionados ao sexo e faixa etária desses pacientes. A presença do $H$. pylori e do genótipo bacteriano foi detectada utilizando a PCR. As biopsias gástricas foram avaliadas histologicamente. Resultados - Observou-se uma prevalência de $91 \%$ da infecção pelo $H$. pylori, sendo mais frequente nos portadores de úlcera gástrica e câncer gástrico, nos quais houve predomínio do sexo masculino e a idade foi maior que a dos outros dois grupos estudados. $\mathrm{O}$ genótipo bacteriano predominante foi o s1m1cagA positivo, sendo mais frequentes entre os pacientes com úlcera gástrica, úlcera duodenal e câncer gástrico. Houve associação significante das cepas com o genótipo slmlcagA positivo com maior grau de inflamação, atividade neutrofílica e desenvolvimento de metaplasia intestinal. Conclusão - Nosso estudo demonstra a alta incidência da infecção pelo $H$. pylori nos pacientes analisados em nosso meio, especialmente em portadores de úlcera e câncer gástricos. As cepas virulentas $1 \mathrm{~m} 1 \mathrm{cag} A+$ foram predominantes e estavam associadas a lesões mais graves.

DESCRITORES - Helicobacter pylori. Infecções por Helicobacter. Gastroenteropatias. Genótipo. 


\section{REFERENCES}

1. Araújo Filho I, Brandão Neto J, Pinheiro LAM, Azevedo IM, Freire FHMA, Medeiros AC. Prevalence of Helicobacter pylori infection in advanced gastric carcinoma. Arq. Gastroenterol. 2006;43(4):288-92

2. Ashour AAR, Magalhães PP, Mendes EN, Collares GB, Gusmão VR, Queiroz DMM, et al. Distribution of vacA genotypes in Helicobacter pylori strains isolated from Brazilian adult patients with gastritis, duodenal ulcer or gastric carcinoma. FEMS Immunol Med Microbiol. 2002;33:173-8.

3. Atherton JC, Peek RM, Tham KT, Cover TL, Blaser MJ. Clinical and pathological importance of heterogeneity in vacA the vacuolating cytotoxin gene of Helicobacter pylori. Gastroenterology. 1997;112(1):92-9.

4. Ayres M, Ayres MJ, Ayres DL, Santos AS. Bioestat 5.0. Aplicações estatísticas nas áreas das ciências biológicas e médicas. Sociedade Civil Mamirauá MCT - CNPq, Belém, 2007:364p.

5. Blaser MJ, Atherton JC. Coadaptation of Helicobacter pylori and humans: ancient history, modern implications. J. Clin. Invest. 2009;1(119):2475-87.

6. Blaser MJ, Berg DE. Helicobacter pylori genetic diversity and risk of human disease. J Clin Invest. 2001;107(7):767-73.

7. Bolek BK, Salih BA, Sander E. Genotyping of Helicobacter pylori strains from gastric biopsies by multiplex polymerase chain reaction. How advantageous is it? Diagn Microbiol Infect Dis. 2007;58(1):67-70.

8. Brito CA, Silva LM, Jucá N, Leal NC, de Souza W, Queiroz D, Cordeiro F, Silva NL. Prevalence of cagA and vacA genes in isolates from patients with Helicobacter pylori-associated gastroduodenal diseases in Recife, Pernambuco, Brazil. Mem Inst Oswaldo Cruz. 2003;98(6):817-21.

9. Casali JJ, Franzon O, Kruel NF, Neves BD. Análise epidemiológica e emprego do teste rápido da urease em pacientes com úlcera péptica perfurada. Rev Col Bras Cir. 2012;39(2):93-8.

10. Figueiredo C, Van Doorn LJ, Nogueira C, Soares JM, Pinho C, Figueira P, Quint WG, Carneiro F. Helicobacter pylori genotypes are associated with clinical outcome in Portuguese patients and show a high prevalence of infections with multiple strains. Scand J Gastroenterol. 2001;36:128-35.

11. González-Vázquez R, Herrera-González S, Cordovs-Espinoza MG, Zúniga G, Giono-Cerezo S, Hernández- Hernández JM, León-Ávila G. Helicobacter pylori: detection of iceA 1 and iceA 2 genes in the same strain in Mexican isolates. Arc Med Res. 2012;43(5):339-46.

12. Gwack J, Shin A, Kim CS, Ko KP, Kim Y, Jun JK, et al. CagA-producing Helicobacter pylori and increased risk of gastric cancer: a nested case-control study in Korea. British Journal of Cancer. 2006;95(5):639-64.

13. Hammar M, Tysziewicz T, Wadstrom T, O'Toole PW. Rapid detection of Helicobacter pylori in gastric biopsy material by polymerase chain reaction. $\mathrm{J}$ Clin Microbiol. 1992;30(1):54-8.

14. Higashi H, Tsutsumi R, Fujita A, Yamazaki S, Asaka M, Azuma T, Hatakeyama M. Biological activity of the Helicobacter pylori virulence factors CagA is determined by variation in the tyrosine phosphorylation sites. Proc Natl Acad Sci USA. 2002;99(22):14428-33.

15. Kim N, LimI SH, Lee KH, Choi SE, Jung HC, Song IS, Kim CY. Long-term effects of Helicobacter pylori eradication on intestinal metaplasia in patients with duodenal and benign gastric ulcers. Dig Dis Sci. 2000;45(9):1754-62.

16. Komen NA, Bertleff MJ, Van Doorn LJ, Lange JF, de Graaf PW. Helicobacter genotyping and detection in peropetative lavage fluid in patients with perforated peptic ulcer. J Gastrintest Surg. 2008;12(3):555-60.

17. Martins LC, Corvelo TC, Demachki S, Araujo MT, Assumpcao MB, Vilar SC, Freitas FB, Barbosa HP, Fecury AA, do Amaral RK, Dos Santos SE. Clinical and pathological importance of vacA allele heterogeneity and cagA status in peptic ulcer disease in patients from North Brazil. Mem Inst Oswaldo Cruz. 2005;100(8):875-81.

18. Martins LC, Corvelo TCO, Oti HT, Barile KAS. Seroprevalence of antibodies against Helicobacter pylori CagA antigen in patients with gastric ulcer in the North region of Brazil. Rev Soc Bras Med Trop. 2002;35(4):307-10.
19. Meyer-ter-Vehn T, Covacci A, Kist M, Pahl HL. Helicobacter pylori activates mitogen-activated protein kinase cascades and induces expression of the proto-oncogenes c-fos and c-jun. J Biol Chem. 2000;275(21):16064-72.

20. Misiewicz JJ. The Sydney System: a new classification of gastritis. Introduction. J Gastroenterol Hepatol. 1991;6(3):207-8.

21. Nogueira C, Figueiredo C, Carneiro F, Gomes AT, Barreira R, Figueira P, et al Helicobacter pylori genotypes may determine gastric histopathology. Am. J. Pathol. 2001;158:647-54.

22. Nomura M, Lee J, Stemmermann GN, Nomura RY, Perez-Perez GI, Blaser MJ Helicobacter pylori CagA seropositivity and gastric carcinoma risk in a Japanese American population. J Infect Dis. 2002;186(8):1138-44.

23. Odenbreit S, Puls J, Sedlmaier B, Gerland E, Fischer W, Hass R. Translocation of Helicobacter pylori CagA into gastric epithelial cells by type IV secretion. Science 2000;287(5457):1497-500.

24. Queiroz DM, Mendes, EN, Carvalho AS, Rocha GA, Oliveira AMR, Soares AST, et al. Factors associated with Helicobacter pylori by a cagA-positive strain in children. J Infect Dis. 2000;181(2):626-30.

25. Ribeiro ML, Godoy AP, Benvengo YH, Mendonca S, Pedrazzoli Jr J. Clinical relevance of the cagA, vacA and iceA genotypes of Helicobacter pylori in Brazilian clinical isolates. FEMS Immunol Med Microbiol. 2003;36:181-5.

26. Romero-Adrián TB, Leal-Montiel J, Monsalve-Castillo F, Mengual-Moreno E, McGregor EG, Perini L, Antúnez A. Helicobacter pylori: Bacterial Factors and the Role of Cytokines in the Immune Response. Curr. Microbiol. 2009;60:143-55.

27. Ricci V, Romano M, Boque P. Molecular cross-talk between Helicobacter pylor and human gastric mucosa. World J Gastroenterol. 2011;17(11)1383-99.

28. Santos SEB, Guerreiro JF. The indigenous contribution to the formation the population of the Brazilian Amazon region. Genetics and Molecular Biology. 1995; 18:311-5

29. Selbach M, Moese S, Hauck CR, Meyer TF, Backert S. Src is the kinase of the Helicobacter pylori CagA protein in vitro and in vivo. J Biol. Chem. 2002;277(9):6775-8

30. Segal ED, Cha J, Lo J, Falkow S, Tompkins LS. Altered states: involvement of phosphorylated CagA in the induction of host cellular growth changes by Helicobacter pylori. Proc Natl Acad Sci. 1999;96(25):14559-64.

31. Silva Jr MR, Vinagre RMDF, Silva AV, Oliveira CSF, Santos KN, Costa RAA, et al. Difference in virulence markers between Helicobacter pylori strains from the Brazilian Amazon Region. Rev Soc Bras Med Trop. 2013;46(3):358-60.

32. Sugimoto M, Yamaoka Y. Virulence factor genotypes of Helicobacter pylori affect cure rates of eradication therapy. Arch. Immunol Ther Exp. 2009;57(1):45-56.

33. Thomazini CM, Pinheiro NA, Pardini MI, Naresse LE, Rodrigues MAM Helicobacter pylori and gastric cancer: distribution of cagA and vacA genotypes in patients with gastric carcinoma. J Bras Patol Med Lab. 2006;42:25-30.

34. Tummuru MK, Cover TL, Blaser MJ. Cloning and expression of a high Molecular mass major antigen of Helicobacter pylori: evidence of linkage to cytotoxin production. Infect Immun. 1993;61(5):1799-809.

35. Van Doorn LJ, Figueredo C, Mégraud F, Pena S, Midoo P, Queiroz DMM, et al. Geographic distribution of vacA allelic types of Helicobacter pylori. Gastroenterology. 1999;116(4):823-30.

36. Vinagre RMD, Campos BP, Sousa RMP. Case study of stomach adenocarcinoma conducted at a cancer referral hospital in northern Brazil. Arq Gastroenterol. 2012;49(2):125-9.

37. Vinagre RMDF, Corvelo TCO, Arnaud VC, Leite ACK, Martins LC. Determinação das cepas do Helicobacter pylori e do polimorfismo do gene da interleucina-8 em pacientes com câncer gástrico. Arq Gastroenterol. 2011;48(1):46-51.

38. Vinagre RMDF, Vilar e Silva A, Fecury AA, Martins LC. Role of infection and lifestyle habits in the development of gastroduodenal diseases in a population from the Brazilian Amazon. Arq Gastroenterol. 2013;50(3):170-4.

39. Wada A, Yamasaki E, Hirayama T. Helicobacter pylori vacuolating cytotoxin, VacA, is responsible for gastric ulceration. J Biochem. 2004;136(6):741-6.

40. Yakoob J, Abid S, Jafri W, Ahmad Z, Ahmed R, Islam M. Distribution of Helicobacter pylori virulence markers in patients with gastroduodenal diseases in Pakistan. BMC Gastroenterology. 2009;9(87):1-7. 